\title{
Reconceptualizing CSR in the Media Industry as Relational Accountability
}

\author{
Mollie Painter-Morland ${ }^{1,2}$ ([) $\cdot$ Ghislain Deslandes $^{3}$
}

Received: 31 July 2014/Accepted: 2 February 2016/Published online: 3 March 2016

(c) The Author(s) 2016. This article is published with open access at Springerlink.com

\begin{abstract}
In this paper, we reconceptualize CSR in the media industries by combining empirical data with theoretical perspectives emerging from the communication studies and business ethics literature. We develop a new conception of what corporate responsibility in media organizations may mean in real terms by bringing Bardoel and d'Haenens' (European Journal of Communication 19 165-194 2004) discussion of the different dimensions of media accountability into conversation with the empirical results from three international focus group studies, conducted in France, the USA and South Africa. To enable a critical perspective on our findings, we perform a philosophical analysis of its implications for professional, public, market, and political accountability in the media, drawing on the insights of Paul Virilio. We come to the conclusion that though some serious challenges to media accountability exist, the battle for responsible media industries is not lost. In fact, the speed characterizing the contemporary media environment may hold some promise for fostering the kind of relational accountability that could underpin a new understanding of CSR in the media.
\end{abstract}

Mollie Painter-Morland

paintermorland@gmail.com; mollie.pm@ntu.ac.uk

Ghislain Deslandes

deslandes@escpeurope.eu

1 Management Division, Nottingham Business School, Burton Street, Nottingham NG1 4BU, UK

2 Coca-Cola Chair for Sustainability, IEDC-Bled Business School, Bled, Slovenia

3 ESCP Europe, 79 Avenue de la République, 75011 Paris, France
Keywords Corporate social responsibility $\cdot$ Media Organizations - Media Ethics - Speed · Paul Virilio . Relational accountability

\section{Introduction}

Finding a satisfactory conceptualization of CSR in the media industries is a difficult task, both for the fields of business ethics and for communication studies. One reason for this is that the roots of many media organizations lie in the journalism profession, and as such, professional ethics and business ethics must be closely aligned in this specific industry (Richards 2004). To discuss this problem, business ethics scholars have mainly focused on adapting Caroll's model to media organizations (Ingenhoff and Koelling 2012, p. 157), starting from the media's editorial responsibility, which is considered as fundamental. This responsibility relates especially to ethical standards within the journalism profession, which center on values such as independence, objectivity, diversity, pluralism, and 'truthfulness' (Ingenhoff and Koelling 2012, p. 155). According to these authors, this primary and essential responsibility extends naturally, but only secondarily, to employees, to environment and to society in general. Some authors in fact argue that before becoming a hot topic, CSR in the media industry has long been considered with skepticism by these organizations' executives (Lee and Caroll 2011; Tench, Bowd and Jones 2007). It is only in recent years that a concern for the legitimacy and reputation of their companies made this a more urgent priority. In this industry characterized by fast-paced change, conglomerates have also adapted as slowly as possible some international best practices in terms of corporate governance (Van Liedekerke 2004). 
Communication scholars find their points of orientation toward a definition of CSR in the complex network of accountabilities that are at play within the media industry. Bardoel and d'Haenens (2004, p. 171) quote Hodges in arguing that "responsibility has to do with defining proper conduct; accountability with compelling it." This approach suggests that there is an implicit relationship between responsibility and accountability, which we will endeavor to make more explicit (Painter-Morland 2012, p. 84). In fact, we believe that exploring this relationship may allow us to offer a satisfactory conceptualization of CSR in the media industries. Responsibility relates to the societal needs that we expect media professionals (especially the members of the newsroom) to respond to. Accountability relates to the way in which societal structures set up constraints that hold professionals accountable for their fulfillment of the responsibilities given to them in their various relationships to stakeholders and structures. We believe that the relational constraints emerging from the interplay between individual accountability and structural accountability work together to offer is a satisfactory conceptualization of CSR in the media industries. It would thus be important to clarify how current accountability challenges in the media industries can assist us in retrospectively defining the responsibilities that the media has toward society.

To this end, we build our approach in four distinct steps. First, we review the literature on CSR in the media industries to inform our own approach to it. Our aim is to broaden Bardoel and d'Haenens' analysis of the relation between media accountability and media responsibility. Secondly, we explain our method for conducting our empirical investigation via focus groups discussions on three continents. This analysis enables us to highlight particular challenges that emerge in terms of media accountability. Thirdly, our analysis of the collected data indicates that the speed of interactions in the media industries poses distinct dangers to professional, public, market, and political accountability. We offer an in-depth study of these challenges, drawing on the thoughts of Paul Virilio, who is the philosopher most closely engaged with addressing the ethical consequences of speed in our hyperconnected societies. In a fourth and final step, we move beyond the challenges posed to various forms of accountability in the media to reconstruct corporate responsibility as the product of relational accountability (Painter-Morland 2006, 2007).

As such, accountability moves from being accountable for a certain set of responsibilities toward being relationally responsive toward all stakeholders in society, and relationally shaped by participation in structures and power dynamics (Painter-Morland 2012, 2013). From this perspective, the moral agency operative in this environment can only be understood if certain structural features of the profession are taken into account. This means that responsibility does not reside only, and not even primarily within distinct professionals, but in the relational constraints emerging from interconnected networks that are accountable toward one another.

\section{Insights from the Literature}

A number of distinct discourses seem to have emerged in the recent literature on CSR in media organizations. Grayston (2010, p. 161), for instance, distinguishes two distinct areas of interest and concern: corporate responsibility in the media and corporate responsibility of the media. The first of these relate to media organizations' attentiveness to conventional CSR issues in other companies, while the latter relates to concerns such as fairness, access, accuracy, taste/decency, media policies, national laws and ethics, as well as to how media organizations pursue and report on their own corporate responsibility.

Most publications in the area of media and CSR focus on how media organizations report on ethics and CSR in other organizations. Lee and Caroll (2011, p. 119) investigate how media attention to CSR issues has increased in different countries over a period of 25 years in the newspaper industry. This provides a justification of corporations' efforts to publicize their CSR policies and initiatives, since it raises public awareness about these issues. Using Caroll's (1999) four dimensions of CSR in their study, they demonstrate how the concept of CSR has become multidimensional and show that interest in organizations' ethical duties became prominent only in the early 2000s. They also reveal how the treatment of CSR by the news media has evolved over time depending on the different dimensions: if a negative tone about CSR in the media has been generally prevalent, media criticism of corporations' lack of ethical responsibility has increased while, at the same time, the number of negative articles in the legal and philanthropic dimensions has decreased. Tench, Bowd, and Jones (2007, p. 361) found that media professionals either have a realist (CSR is self-interested, but can transform business for the better) or a cynical view (CSR is pursued for perception-purposes only and makes no substantive difference to business and usual) of the CSR activities that they report on, and tend to focus more on negative stories than positive ones.

The fact that media organizations increasingly report on CSR issues in other companies seems to have led to an enhanced awareness of their own corporate social responsibility. Ingenhoff and Koelling (2012) have found that it is 
increasingly important for media organizations to be perceived as 'good corporate citizens.' Han et al. (2008) studied the development of the Korean newspaper industry's CSR activities. They discuss how this industry's CSR agenda has been shaped over time by factors such as prominent political debates, emerging public concerns, cooperation between journalists and corporations, and CSR strategies aimed at reputational benefits in response to stakeholder demands. In addition to their role as reporters of CSR debates, media organizations themselves "have to demonstrate social responsibility performance, build a corporate road map and clear vision, and restore the essential press identity necessary for survival..." (Han et al. 2008, p. 678).

Within the broader realm of CSR of media organizations, Ingenhoff and Koelling (2012, p. 161) distinguish between (1) issues of media governance, and (2) issues relating to the media's engagement with CSR within their own internal activities. Media governance relates to issues such as journalistic guidelines, control mechanisms, sanctions, competition, editorial independence, separation of ownership and editorial domains, self-promotion, minorities, high-quality reporting, and the involvement of recipients. CSR within media organizations relates to how they strive to protect the environment, how they treat and develop their employees, their support of social programs and projects in society, etc. Media organizations however risk being accused of cynically pursuing instrumental, selfinterested PR through their CSR activities. In fact, if this were to happen it would be a case of 'what goes around, comes around.' The fact that media professionals have a cynical, or at best realist view of the CSR in other companies they report on, naturally also has implications for their participation in their organizations' internal corporate responsibility efforts.

What however becomes clear is that dealing with CSR in the media industries requires a much more nuanced definition-one that acknowledges the complex network of accountabilities that are at play within the media industry. There is an implicit relationship between responsibility and accountability that is worth articulating for the purposes of this paper. Combining the ethical responsibility of individual professionals with the societal structures that serve to hold journalists accountable for the fulfillment of the responsibility given to them, creates a space of relational constraints (Painter-Morland 2013, p. 7) that we believe could lie at the heart of CSR in the media industries. We therefore proceed to indicate how current accountability challenges in the media industries can assist us in retrospectively defining the responsibilities that the media has toward society. Drawing on Bardoel and d'Haenens (2004, p. 173), we will be exploring various levels of media accountability, drawing on further literature to highlight the emerging challenges. They articulate 4 types of media accountability:

Professional accountability is linked to those ethical codes and performance standards that should mitigate an over-reliance on the market and politics (Bardoel and d'Haenens 2004, p. 173). Our own research and a number of other studies however cast doubt on whether professional accountability (at least in its original interpretation as being concerned with accuracy, objectivity, transparency, and fairness) succeeds in influencing contemporary media professionals.

Public accountability relates to the media's direct relationship to citizens, in addition to its relationship to the market and to the state. In their study on the sustainability of news journalism and newsroom management, Philips and Witschge (2012, p. 3) contend that: "Information is to democracy what oxygen is to fire"; a threat to the media's ability to ensure accountability within various societal spheres, poses a threat to democracy itself. Since there is no real democracy without well-informed citizens, media organization's responsibility at its core is to provide quality news to give future voters the right information at the right time, in order to exercise their role as citizens (Grayston 2009). The media's role in the run-up to the last economic crisis is instructive in this regard. Stiglitz (as reported by Schiffrin 2011) remarked that overall, during this period of time, the press acted more like a cheerleader as the bubble grew rather than as a check, or a warning light (Schiffrin 2011). If editorial staff were theoretically willing to respect values like transparency, objectivity, honesty, civic, and democratic responsibility, in practice, their preferences were modified to privilege speed, audience ratings, and the spectacle. As a result, media professionals now need to reevaluate the conceptual framework upon which their professional ethics has been built.

Market accountability is bound up with the system of supply and demand, and as such, media organizations have to deal with the public's free choice and preferences, and operate efficiently to provide desirable products and services at a competitive price.

Political accountability refers to regulations, policies, and procedures stipulating how media companies are structured, and how they function.

Recent developments in the media industries have served to intensify the accountability challenges that media professionals face. The 'digital explosion' and its globalizing force made it more difficult to effect political accountability, since regulations in various states across the globe are difficult to implement and enforce; the Wikileaks saga is here a case in point (Van Puyvelde 2011). It also opened global markets at an unprecedented rate, complicating market accountability. Similarly, public accountability is no longer limited to the citizenry of one's own 
nation state. In this environment, professional accountability is often compromised by intense global competition.

In order to conceptualize CSR in our contemporary context, we will explore how representatives of contemporary media organizations perceive the challenges that they face, and then compare this to Bardoel and d'Haenens' accountability model. Before we do so, we briefly explain the methodology we used to conduct our international empirical inquiry.

\section{Methodology}

Our research was conducted in a number of phases and a different methodological strategy was employed at each stage. In the first phase of this study, we used focus groups to collect information (Blanchet and Gotman 2010). Used for research on organizations, especially in the framework of exploratory studies, the focus group technique offers several benefits: it provides a forum in which a select group of individuals can reflect on topics relevant to the study's theme. This allows participants to identify potentially significant oppositions, develop original ideas, suggest new hypotheses, or make shared feelings explicit (Kehoe and Lindgren 2003; Krueger and Casey 2009). They allowed us, to maximize the number of interactions between professionals (who are seldom available) in a minimum amount of time (Morgan 1997). Our focus groups proved an excellent vehicle for observing the way that media professionals understand the challenges they face in terms of the different types of accountability we mentioned above. It also gave us the opportunity to take advantage of the kind of "free-speech" that journalists usually claim to use among themselves during daily editorial meetings. To provide them this environment of free deliberation that they are accustomed to was especially useful considering the fact that the discussed matters are particularly sensitive. They could reflect openly on how changing structural conditions pitted market accountability versus professional accountability, and political accountability versus public accountability.

The three focus groups convened in our study all met standard methodological requirements (Morgan 1997; Hydén and Bülow 2003; De Singly 1992; Berthier 2006). The participants included editors, journalists, managers, and entrepreneurs in print, telecommunication, and online media companies. Each of the meetings, lasting between two-and-a-half and four hours, were recorded in Paris, Johannesburg, and Chicago, then transcribed in their entirety (Silverman 1993).

We reflected on some of the themes that emerged from the aggregated data through an inductive coding process, using Nvivo. The main finding based on emerging themes was that the speed that characterizes contemporary media organizations raises some distinct accountability challenges. We then turned to abductive methodologies (Alvesson and Skoldberg 2009, p. 4), which involved moving back and forth between the themes emerging from the data, philosophically informed theoretical reflection on the implications of the data, and a survey of existing literature on CSR in the media industries.

We now proceed to analyze the themes that emerged from the focus group discussions and provide a philosophical reading of its implications, drawing on Paul Virilio. Paul Virilio (born in 1932) is a contemporary philosopher, who also describes himself as an architect and urbanist. A large part of his work is focused on the effects of acceleration in late twentieth to early twenty-first century societies, and as such, his oeuvre provides us with interesting concepts with which to analyze the implications of the acceleration that we encounter within the media industry (McQuire 1999; Cubitt 1999).

\section{Focus Group Findings and Implications for Media Accountability}

Our research indicated that media professionals are faced with a number of interrelated accountability challenges (McQuail 1997, 2003), which are all in some way related to the speed that has come to characterize media industries. We believe that we can only understand these challenges if we develop a sense of the interrelationships between threats to individual accountability and changes to the structural dynamics within the profession. One respondent in Paris summarized the situation as follows:

On the one hand, you have a much stronger pressure on every kind of media, regarding the speed, regarding how and how fast they are able to deliver, check and communicate the news to a great number of people. On the other hand, you have another pressure coming from the Internet that is the reader, the spectator or the listener, who is no longer anonymous. Nowadays, he wants to interfere and be part of the media. Internet brought that and I think it's just the beginning. The third point is how classical media, whether it's press, television or radio, are struggling to find a new way to earn money and survive.

We firstly turn our attention to how professional and public accountability have come under threat, and then indicate how this relates to the structural dynamics of changes in market and political accountability. 


\section{Challenges in Terms of Individual Accountability: Threats to Professional Accountability and Public Accountability}

The main findings of our focus group analysis relate to the speed that characterizes contemporary media organizations. In what follows, we will highlight the way in which the identity-crisis emerging in this fast-paced environment threatens both professional and public accountability. We discuss these together since they seem to be interrelated: the demise of professional ethics changed the way in which these individuals view their relationship to the public. Our focus group data suggest that the identity-crisis that professionals experience impacted these individuals on various fronts. Not only could access to the profession no longer be controlled through formal hiring processes, but the increased competition and time-pressures also eroded a commitment to fact checking, objectivity, and taking care around sensitive subject-matter. Challenges in terms of individual accountability and the emergence of new structural dynamics colluded to threaten media accountability in various, interrelated ways. A South African editor of an online publication explains the challenge:

Time pressures have gotten much, much worse because now, you have to beat not only digital agencies, but everyone with a Twitter account and their own YouTube channel and everything. So you're competing against everybody.

This increased competition has intensified the endless race to be first, and to be entertaining or interesting enough the capture and sustain the interest of a public with increasingly shortened attention-spans. A Paris respondent contends:

we're like these insects that run on the water." We're becoming water spiders and this is normal journalism. What is it? It's part of something that is part of journalism but what is it?

Our findings regarding the effect of speed on the media industries is congruent with many studies that have been done on the subject. As Witschge and Gunnar (2009, pp. 38-46) explain, the productivity of journalists is three times higher than it used to be twenty years ago and $41 \%$ of them agree with the fact that "the demand for speed in publishing forces me not to check the facts as carefully as I would like to." The authors also note that facts are usually published as "ongoing news" without any prior checking. The three phases of journalism, i.e., news-gathering, evaluation, and production are now more "compacted."

To fully understand the impact these developments had on individuals, one has to unpack the implications of speed on individual capacities for perception and judgment. Virilio (2008) describes the way in which speed influences our perception and capacities for understanding as dromoscopy. Dromos is the Greek word for race, and scope means 'to observe,' 'to look carefully,' or 'to scan.' Hence, dromoscopy is an attempt to take account of how our perception changes when our experiences of the world flash by at great speed. The world that one comes to know in this way, is one where the past, present, and future is morphed into a fleeting image. Since the distance between the past, present, and future disappears, our capacity to reflect on what happened in the past or to construct a future is compromised. From this perspective, the means of communication of dimensions are simultaneously the extermination of dimensions. 'Real-time' combines and displaces both actual and virtual, creating a new relief (Virilio 2008, p. 113). It is a relief that conditions and structures our perception, impacting on how we view the world, and as a result, changes both ethics and aesthetics as we have come to know it. It is not a world without values, but a world of selective valuation. One may even argue that it creates the kind of space within which certain value orientations can no longer be questioned. One Paris respondent commented that the media environment requires: "Doing first, thinking later." Another laments that "nobody teaches you to be fast and good at the same time. Everyone teaches you how to be a good journalist... but with time!"

Drawing on Virilio, we believe that this erosion of professional judgment that occurs as a result of timepressures can be described as the result of dromology. Dromology refers to the kind of ontology that emerges when dromoscopy is operative. It is the kind of ontology that makes it very difficult to exercise judgment or to formulate any appropriate response. It is the loss of the luxury of time for reflection that poses serious challenges to the profession's most foundational values, such as fairness, objectivity, trust and independence (Steele 2008). Fairness is threatened when limited time does not allow sources and facts to be checked thoroughly. Objectivity and independence are eroded by the pressure that characterize the intense competition to be first, and the need to generate the financial resources that allows one to remain first (as discussed below). 'Objectivity' also becomes a misnomer when media professionals need to put an interesting or entertaining 'spin' on the news in order to sustain audience interest. On the one hand, media professionals respond to what they think the audience needs, and on the other, they continually shape and craft public perception in and through their brands. Yet the loss of 'objectivity' is not something that is mourned by senior media managers. An editor in chief of a popular celebrity magazine in South Africa explains: 
You know we don't try to be objective, we don't pretend to be objective. We know it's non-sense there's no such thing as objectivity.

This insight is reflected in the fact that the term 'objectivity' has disappeared from the ethical code of the U.S. Society of Professional Ethics. This has led some scholars, like Hunter and Van Wassenhove (2009) to suggest that we have replaced the myth of objectivity with the myth of transparency (which is for example the slogan of Wikileaks and its founder Julian Assange). What this entails, is that honesty rather than neutrality becomes the watchword, and that this determines the trustworthiness of professionals. But the question is whether transparency as such can be a substitute for the duties of honesty and objectivity that used to be the basis of professional journalists' responsibility toward the public, at least as defined by bodies such as the Hutchins Commission. Their 'good governance' rules for the media included clear deontic principles, requiring of media outlets to be truthful, correct, impartial, honest, and ultimately accountable (Van Liedekerke 2004, p. 36). Our focus group results indicate that the loss of professional values has changed the way media professional relate to the public, and how they perceive both their professional and public responsibilities. One can however not understand this simply in terms of the erosion of individual accountability. Speed not only impacted individuals, it also changed structures. We therefore now turn to the interrelationship between these individual challenges and structural changes in the profession.

\section{Challenges in Terms of Structural Accountability}

\section{Monetizing Speed: a Threat to Market Accountability}

Like any business, media organizations are subject to forces of supply and demand, and its management has a fiduciary duty to make the business financially successful. In our research, the need to appeal to a specific audience was more often than not mentioned in the context of ensuring financial sustainability. The speed of media consumption causes audiences to demand packaged and digested material that can be consumed quickly, at low or no cost. When the question of what people expect from the news came up in the South African focus group, one editor answered:

Fast food. Hamburgers. Green beans are good for them. Broccoli is good for them. I know it. But I'm not giving them broccoli because they won't buy it.

The effect of speed is again evident here-information must be consumed on the go, quickly, efficiency. One can clearly see that the concern is not for the long-term 'health' of the public arena, but for the immediately consumable news. Because of the fact that much of the media has become 'infotainment' (Stoll 2006), media professionals are constantly under pressure to build a brand that 'sells.' The need to build a specific brand and to find ways to monetize the various uses of technology that are available to the media were common themes emerging from the focus groups. In Chicago, the concern for resources is reiterated:

It's all about money. It all comes down to resources and the things like $\mathrm{M}$ talked about and I think our competition has increased partly because of the lack of resources.

Media professionals constantly find themselves under pressure to maintain a balance between the integrity of their own brands and the need to satisfy their audience's demands to be entertained. As one newspaper editor quite bluntly puts it: "You are keeping yourself busy with news that's sells. In the end we are all sluts. We need to survive." What emerged from the discussions is that media professionals find themselves in a unique predicament. On the one hand, it is their capacity to select, filter, and evaluate information that sets them apart from the bloggers, or the general public with their twitter and Facebook accounts. The dilemma that editors face is that their organizations' financial sustainability seems to be pitted against the professional journalist's role in offering meaningful perspective. Unfortunately, the speed with which journalists have to work makes it impossible to find brand new news items, digest it, evaluate the implications, and stimulate public interest in its long-term effects.

This causes structural accountability challenges. In order to deliver this, at speed, and cost-effectively, new practices and routines are emerging. As Phillips and Witschge (2012, p. 9) indicate, it is now established journalism practice to "Do what you do best and link to the rest." This has become necessary because the consumer is increasingly unwilling to pay for news, and also prefers to read only selected parts of the available news. The fact that many media organizations, as they always did in the past, continue to select and tailor the news toward their established brand, allows the public to align the news that they receive with their specific values and preferences. As such, it allows them to find some sense of identity in a world that otherwise displays disorienting complexity. On the downside, it may also perpetuate prejudice and entrench ideological bias. For example, members of the public can select a television station or newspaper that filters and interprets the news from a specific political position.

Within the journalism literature, reference is also made to an important group of new entrants into the news business, namely the 'aggregators.' The main threat that 
aggregation sites like Google news pose to journalism ethics is that it undermines the unique selling point of the news organization, i.e., the scarcity value of being first with the news (Phillips and Witschge 2012, p. 4). Although this may have always been the case, focusing predominantly on the function of 'aggregation' does not demand of journalist to fact-check sources or to seek out contrary perspectives. Van Liedekerke (2004, p. 39) underscores this by mentioning the danger presented by the creation of certain 'virtual groups' with clear group identities. This structuring of perception undermines both the individual discretion of the journalist, and of the consumer. It is replaced with group identities shaped around ideological positions.

Virilio (2009, p. 25) argues that one of the effects of dromoscopy and dromology is that we are incapable of acknowledging or understanding our limits. A concern for limits is important in order for us to have any sense of perspective. In his introduction to Virilio's Speed and Politics, Benjamin Bratton (2006, p. 16) explains:

Today information is architecture by other means, framing and contouring the relative motility of social intercourse.

He describes how graphical user interfaces, or GUI, narrate the affordances that they inscribe. Through them, certain instrumental purposes dictate how and what we can know about our world. The structuring of perception involved in 'fast-food' content makes it difficult for professionals to offer their audience a variety of perspectives, let alone critical reflection. In the Paris focus group, there was a lot of discussion of the scrolling news banners that flash across our screens constantly. Not only do they mimic the immediate and crucial financial world's market data, but they frame and determine our understanding of political news and cultural events in those very same terms. What therefore should not be discounted, is the media's power to impose its own temporal structures on society (Rosa, 2010). Virilio claims that we have all become 'imageilliterates' or 'deaf-mutes,' people who have been deprived or their receptor organs through the globalization of the gaze (Virilio 2000, pp. 137-148). There are certainly some elements of the media organizations that seem to suggest that there is a funneling of information at great speed, which does not allow a full range of perceptual evaluation to operate. In Paris, there was much discussion about the way in which certain headings are mindlessly repeated in various media outlets. As one respondent explains:

L, you said that the contact points with the audience have been multiplied... But what sometimes strikes me is when you do an inventory of the information collected during the day. You look at the three main news channels and they are pretty much all the same.
Even when you go to Google News, the titles of the dispatches on ten different publications are the same! There is no additional information, but there are a thousand contact points!

An added complication is that many senior media professionals are often too busy seeking advertising revenue, or developing new business models to monetize the use of new technologies, to play this role of curator, designer, and mediator. The selection of news items and the evaluation and commentary are often left to junior staff members who lack the experience and perspective to stimulate public reflection on the news. Difficulties in finding sustainable business models may in fact be the very threat to the profession's most important functions.

\section{Dromocracy: A Threat to Political Accountability}

The relationship between the media and political organizations has always been a controversial one. In many contexts, governments had great control over their public broadcasters (BBC in England, ARD in Germany etc.), and ownership and competition rules played an important role in how the ongoing struggle for media independence was played out. Although our focus groups did not ask specific questions about the role that governments play in influencing media policies and media management, and though it did not emerge as a major theme, some respondents commented on the way in which they can interfere with the media's independence. When asked whether the media is facing a 'crisis,' one South African respondent explained:

I think it depends what the crisis is... (...) don't know where their next revenue stream is coming from ..... I think here it is much more the political involvement. Fingers in everywhere. I know how much prodding there is and from somebody that was licensed. For instance when I joined XXX, we weren't licensed we were sort of just grandfathered. Subsequently we've been licensed. The argument for us has always been we are a commercial entity and therefore we are not going to adhere to these, like, political kind of little guidelines or pick up the phone and say you can't air that, you can't air this. Whereas now that we're regulated, it is becoming a lot more, you know "you must speak to so and so about content", which is not necessarily what you have done before. .... I think that is really a problem for all of us.

In France for instance, where public subsidies in the media are very important (more than $10 \%$ of the turnover of the newspapers come from that source), the supposedly independent high-authority in audiovisual ("Conseil supérieur de l'audiovisuel") is composed of 9 members who are 
nominated by the President of the National Assembly (3), the President of the Senate (3), and of the President of the French Republic (3). Other public institutions such as the (CSA) in France, has the power to allocate radio and television frequencies and grant or revoke broadcasting licenses. It is thus clear that in some contexts there is a close relation between political power, economic performance, and legal viability in the media industry. Furthermore, one cannot deny the political influence of media leaders, usually presented as 'moguls.' Silvio Berlusconi in Italy and Michael Bloomberg in the USA are cases in point. They have both been important media leaders in their respective countries (with their media giants Mediaset and Bloomberg) while being political leaders as well (the former as prime minister of a G8 country and the latter as mayor of one of the most influential cities in the world). Through his company Mediaset, Berlusconi was the main private actor in the Italian media industry. As such, he could nominate the top-managers of public TV stations for many years. This gave him de facto control the whole sector. Van Liedekerke (2004, p. 32) has drawn attention to the need to consider the interactions between moguls, management, and editorial teams in such contexts in order to ensure appropriate checks-and-balances. Furthermore, Van Liedekerke explains (2004, pp. 33-34): "Strong ownership rules often favour the creation of local empires, where the danger of too close a relationship between political and media power is even larger than in the case of a foreign owner coming in. (...) In this sense media ownership rules can be counterproductive from a political point of view."

A lack of distance between politicians and media professionals can also limit the media's ability to meet its social responsibilities. This is one of the main lessons we can get from the News of the World hacking-phone scandal. Before entering jail last July for conspiracy to intercept voicemails, Andrew Coulson was David Cameron's personnel director of communication (replaced in 2011 by an other media professional). Adding to this the fact that many media organizations do not always operate according to best practice standards for corporate governance (Van Liedekerke 2004, p. 32), and the risks in terms of accountability becomes clear. The fact that the media often function as a so-called '4th office' (next to the legislative, executive and juridical functions of government) makes it important to consider and monitor the nature of its relationship to the political establishment.

The effect of speed, as reported by our respondents, intensifies the challenge. The fast-paced change in the media industry is exacerbating political accountability problems. Legal systems cannot catch up with the emergence of new technology - everything is moving at lightning pace (which makes regulation a difficult, if not impossible, task). Grayston (2004, p. 166) also mentions "the general speeding up of modern life." For him this leads to a 'sound-bite' journalism that is less suited to covering stories about corporate responsibilities, which require analysis and contextualisation. Virilio argues that the spectacle creates a visual preoccupation that numbs other sensibilities, and maybe precisely the kind of sensibilities that we require for ethical and political deliberation. As one respondent put it:

The more the show, the less ethics for me. (...) I mean truth is different from being nice, from being spectacular.

From Virilio's (2008, p. 112) perspective, truth is the first victim of speed. The result of what he describes as the 'defeat of facts,' is a complete disorientation in relation to reality. The disqualification of distance undermines our capacity to act, because we have no space to act. Within the professional realm, we lose the mediating value of action and practice, which used to ground professional ethics, while the immediacy of interaction gains in comparison. Virilio (2000, pp. 61-62) warns that the result would inevitably be an 'oblivion industry,' within which the 'market of the visible' dictates.

Virilio would describe this as the replacement of words and things with predetermined codes. He views the automatic calculability that result from this as the obvious effect of the symbiosis between humans and technology, and its processes of social conditioning that outstrips any intelligent thought. The media's desire for spectacle, which requires constant snooping and surveillance, does seem to suggest that Virilio is correct in arguing that speed impoverishes our perception, dulls our senses, and turns us into Cyclopses with an insatiable desire to see everything. This is evidenced in our constant fascination with the lives of celebrities and politicians, or even on the mundane interactions of everyday mortals in reality shows. Paradoxically, this turns the contemporary home into a cell of surveillance from where we are simultaneously the watchers and the watched (McQuire 1999, p. 150). Virilio fears that 'real-time' distribution of images across geographically dispersed audiences in their own private spaces offers a perception of 'global completeness' that redefines the social contract as we know it (McQuire 1999, p. 145).

The speed of reporting has led also certain outlets to resort to homogenizing terminology to fit their 'brand,' thereby diluting the role of individual journalist in interpreting political events. Control over individual accountability makes little sense without an understanding of the emergent dynamics within structural accountability (Painter-Morland 2013). Barkho's (2010) analysis of the battle between $\mathrm{CNN}, \mathrm{BBC}$, and $\mathrm{Al}$ Jazeera in their coverage of 
major international events is a good example of how reporters from these news channels actually use guidelines that dictate the use of certain words regardless of the circumstances of the facts reported. Concerning the IsraeliPalestinian conflict for instance, the vocabulary used to name the Palestinian forces of Hamas depended not on the individual journalist but rather on the news outlet for which the journalist works. A journalist must first and foremost represent the values of his news organization (referenced in its guidelines), which depend simultaneously on a specific market position, on available editorial space, and on professional practices that are established and reinforced over time (Bourdieu 2011). In this sense, the organization's ethics shapes the individual's response. A collective form of agency emerges, and their responsibilities toward a citizenry are spread across countries and continents. Although this is a challenge for CSR in all industries, the problem is exacerbated by the fact that it seems as if media professionals' professional ethics have been eroded without it being replaced by any other structural checks-and-balances, which in fact threatens democracy itself.

As a specialist in analyzing the effects of technology in relation with speed, Virilio paints a dismal picture of what has happened to our capacities for democratic action as a result of the accelerated environment within which we operate. He argues that democracy has been replaced with dromocracy, i.e., public interaction that is determined by the speed of the race within which we are all involved in. According to Virilio (2000, p. 109), such a dromocracy is characterized by a 'social automatism' within which decisions emerge as a kind of reflex reaction. This 'reflex democracy' is in fact the result of social conditioning. Speed outstrips thought or any intelligent action. The absence of deliberation is compensated for by the predominance of fleeting images, which serve to reassure the audience of its truth by virtue of its sheer frequency (Table 1).

\section{Discussion: The Possible Emergence of Relational Accountability}

Our analysis revealed that the pressures that are influencing market and political accountability exacerbate individual accountability challenges, i.e., the challenges to professional and public accountability. Because we can no longer rely on professionals as transcendental subjects with distinct values and autonomous decision-making capacities, some other forms of constraint are required to ensure responsibility in the media industries. As it stands, the speed of consumption is emerging as a strong relational force influencing the functioning of the media industries. Similarly, the new digital environment and the ownership structures and forms of new media organizations, pose questions regarding political accountability. In this context, it seems urgent to rethink the functioning of agency in the media profession. Drawing on Painter-Morland's (2013) notion of relational accountability, we hope to offer some perspectives on how the relationships between individual agents and consumers, funders, legislators, and pressure groups may act as relational constraints that shape responsibility in the media industries.

Indeed, many journalists have to strike a balance between informing their audience and satisfying their audiences' specific preferences. The importance of designing a consumer experience is reiterated in the South African focus group's suggestion that media professionals have become 'curators.' As one editor put it:

I think we become curators. That's a word I've heard a lot recently. You as a consumer pick a brand or an outlet that you respect because of whatever they've delivered to you in the past, and it might be different for all of us. You trust that person, just like you trust a best friend to recommend a restaurant. They curate the information that is out there.

From this perspective, media professionals play an important role in selecting, evaluating, and packaging material for their specific audience. In a time of overwhelming amounts of information, this is a crucial role to play, and requires trust to be sustained between the media professional and her/his audience. Although many respondents still mention the importance of 'trust,' they seem to be redefining trust in this fast-paced environment. For instance, in South Africa, there was a strong emphasis on the importance of building a trusted brand that attracts a specific audience because of its capacity to deliver the news that serve the readers' or viewers' specific interest and value-preferences. This means that media professionals have to select content that match their audience's interests, package it in their audience's favored format and ensure that it is always presented in a way that is consistent with their audience's beliefs. Does this necessarily turn media audiences into deaf-mutes, or Cyclops, without the capacity for judgment?

We can only escape Virilio's dismal conclusions if we manage to question his understanding of individual agency. We believe our focus group data give us ample reasons to do so. Commentators on Virilio's work have argued that his conceptions of 'truth' and of the 'subject' can be challenged from a poststructuralist perspective. McQuire (1999, p. 153) points out that Virilio upholds strict binary splits between 'image' and 'reality,' and 'self' and 'context.' This may lead him to believe that the 'truth' and 'selfhood' are contaminated or destroyed when contemporary experience is filtered through particular frame or 
Table 1 Focus group findings on media accountability (Adapted from Bardoel and d'Haenens (2004, p. 173))

\begin{tabular}{ll}
\hline Dimensions of media accountability & Focus group insights \\
\hline Individual accountability & Identity crisis \\
Professional responsibility: ethical codes and performance standards & Transparency instead of objectivity \\
Public accountability: relationship to citizens & Monetizing speed \\
Structural accountability & Digitalization and globalization \\
Market accountability: system of supply and demand & Political interference \\
Political accountability: formal regulation & \\
\hline
\end{tabular}

context. He does not seem to pay adequate attention to the various well-developed philosophical debates about the interrelationships between 'event' and 'representation,' and 'image' and 'reality.' Nor does he take into account agency-structure interrelationships. Because of this he fails to consider the possibility that emerging technologies and business models may contribute to the development of new professional and citizen self-conceptions that embrace rather than exclude accountability. We believe that media professionals function within agent-customer-context configurations that need not amount to an 'anything goes' attitude, but in fact requires a different kind of moral responsiveness.

Cubitt (1999, p. 128) also pushes back against Virilio's pessimistic conclusions regarding the devastating effect that speed has on the subject's will. Virilio's conclusion that an increase in speed means a decrease in freedom, is based on the flawed assumption that our human freedom is related to the existence of a 'reality' that is degraded by the loss of horizon and optical depth (Cubitt 1999, p. 130). Instead of understanding human subjectivity in terms of the existence of the isolated individual subject, Cubitt (1999, p. 132) argues that identity, individuality, and subjectivity are constructed in and through mediation, and are as such ephemeral, temporary and contingent. However, individuality (including professional identity) emerges through a process of mediation. It is not its foundation. This leads Cubitt (1999, p. 133) to explore the possibility that the fluid subjectivities that characterize online communities could contribute to political action and democracy. In the context of the media industries, we need to explore the ways in which this mediation could have positive effects on professionals' moral responsiveness. In this regard, Charles Taylor's conception of authenticity is helpful. Taylor (1991) argues against the kind of authentic self-referentiality that expresses only the individual's own desires, aspirations, and values, and advocates the self-referentiality that orients the individual in terms of a broad 'horizon on significance' with a variety relational constraints (Painter-Morland and Deslandes 2015).
In our focus groups, many participants commented on the benefits of speed and how it enhanced their interaction with their audiences, thereby building exactly this 'horizon of significance.' We would argue that what emerges is in fact a form of 'relational accountability,' which reflects the changes in expectations between the professional and his/ her audience, and attests to a mutual willingness to be accountable toward one another. During a discussion about public expectations of journalists, the Chicago focus group respondents questioned whether the public actually expects accuracy and objectivity from them: "I don't think anybody believes anymore when they first hear breaking news that you are going to get all the facts." As one South African participant also explains:

People keep coming back and you can come back an hour later and say actually the information we had an hour ago wasn't entirely correct, we've subsequently found an update.

This insight may allow us to rethink the way in which accountability functions within media environments. Painter-Morland (2007, p. 526) argued for a more relational understanding of accountability, which requires of all participants in a network to continually account to one another for their actions in terms of a dynamic set of relationally defined expectations. Instead of holding professionals accountable for the information upon which democracy relies, they must constantly be challenged to be accountable toward those who rely on them for information, and in terms of the emerging sense of normative orientation that emerges from these relationships. What seems clear, is that this will not entail a return to an adherence to abstract professional principles. Instead, a relational understanding of responsibility requires the ongoing moral responsiveness of those involved (PainterMorland 2006, p. 95). In some respects, this is a higher demand, since professionals have to take account of a broad range of specific needs and contexts, as well as the long-term implications of their professional activities. This kind of accountability is not one-directional, but requires 
thoughtful interaction between all the participants in a relational network. Within the media environment, this relational network encompasses media professionals, media consumers, government officials and politicians, business managers, and NGO representatives.

There seems to be a move away from a concern for 'facts' and 'objectivity,' toward a preference for honest and fair engagement and transparency, or as one Paris participants put it: 'transparent doubt.' He describes it as follows:

The feeling I have is we are shifting from the former way to be a journalist and towards a new one. The former one was around the value 'truth' and truth takes time, you have to be sure, to check... and this time of journalism was made of stories, analysis, comments etc. Recently it's been challenged by not truth but direct live testimonies, true stories... I think we have to accept this shift - not to this direct lifebut maybe there's something better to try, which would be 'journalism of doubt', but very transparent doubt.

This approach is confirmed by the editor of a South African celebrity magazine:

the fact is that we're also human, we work to fast deadlines, we get the information to you as fast as we can, but we do work in print. We can't fix what we do, but we say that we make mistakes. We want you guys to come up and say you've found mistakes, tell us what it is and we'll print it. And then again, you make a community of people who are all in it for the same thing.

This specific celebrity magazine rewarded readers who make them aware of errors or updates by donating money to a charity of that reader's choice. In this way, professional responsibilities of the profession is directly linked to CSR activities performed by this media organization. In Paris, the importance of this type of relational checks-and-balances was confirmed. 'Control' goes beyond the journalist or the media professional involved: "Speed caused a loss of control, but also transferred the control of information towards the source rather than the journalist." What seems to be emerging, is a relational trust and credibility that goes beyond the individual journalists or editors to their audience, sources, mentors, and life experience.

Virilio drew attention to the uncritical reflex-like reactions and counter-reactions that characterize a dromocratic dispensation. However, these characteristics may also facilitate a new form of accountability. The focus group discussions seemed to suggest that other forms of democratic engagement may emerge precisely as a result of the speed with which information is disseminated and circulated. One participant in the Chicago group, for instance, remarked on the way in which audience engagement influences the 'credibility' of information:

It goes back to that credibility issue and that engagement issue in how do you engage your audience in a compelling way because people are no longer passive observers of information. They want to feel like they are part of it in some way so... And all of this speed we have to consider the credibility, is this factual? But also is this engaging?

Being the first to introduce new information is no longer enough to ensure audience engagement. Relationships are built over time and are sustained by open communication. Addressing mistakes and disappointments seems to facilitate and enhance relationships of trust instead of undermining it. The ongoing interaction between the media professional and his/her audience is therefore crucial in establishing the checks-and-balances that are needed to develop credibility over time. What becomes important however, is that media professionals play their role as curators within a network of relational checks-and-balances. They have to be made aware of the informational architecture that they create and the way in which this filters public perception. It is the kind of care that can only emerge through time and experience, and as a result, the importance of mentorship, personal self-reflection, and challenging conversations among peers cannot be underestimated.

This may require delivering news fast and on target in terms of one's audience, while at the same time allowing oneself the time to work on the bigger picture and to reflect on developments over time. Time-pressures also create a demand for journalism that allows for news to be easily digested, i.e., interpreted and used, while not compromising longer-term perspectives. A Chicago respondent reflects on a possible solution:

Recently I've been going to different conferences asking people how do we do it quicker and faster and I got a piece of advice from $X$ and she was fantastic because she said don't stop doing what you do, but break off the story into little pieces when you are done, but continue to have because a voluminous investigation because there are certain people looking for that, but then have somebody rewrite it for your blog in such a way that is different or put little pieces on Facebook.

Fostering multiple interactions over time, incrementally adding new perspectives, could be one way on which journalists maintain their accountability toward their audience while responding to audiences need for quick and digestible information. At the same time, audiences 
may be encouraged to accept their own responsibility with respect to the media, by seeking out multiple perspectives over time, suspending quick judgments in order to see how a story unfolds, and engaging with media professionals when criticism or questioning is appropriate. What is needed for relational accountability is to think through the "embeddedness of consciousness and identity in particular historic social relations of time and space" (McQuire 1999, p. 154). Allowing for multiple, albeit quick iterations over time, from different contextual perspectives may be a new way to deal with the fact that truth is always partial, always postponed, and negotiated (Cubitt 1999, p. 135).

The technological advantages that the new digital era affords the journalism profession must be celebrated along with an appreciation of the pitfalls created by the speed it entails. In all focus groups, participants indicated the benefits of speed. In the words of a respondent in Chicago:

I like the speed. I'm appreciating the opportunity to take a business model or a business challenge and utilize so many different vehicles and opportunities to communication directly with the target audience and it just energizes me to always come up with very creative ways to get our messages out.

It seems as if the access to information that the digital environment affords both journalists and their audiences, creates opportunities for mutual challenges and as such, the opportunity for ongoing evaluation and the development of judgment. From this perspective, it becomes clear that the threats to the various levels of accountability can only be addressed if speed is used as an ally to extend and enhance accountability, rather than as a force for undermining it. In more specific terms, let us articulate what this may imply on each level of accountability:

Professional accountability New technologies can be opportunities for the creation of new professional and citizen identities in which relational responsiveness functions as a normative constraint.

Public accountability The media's relationship with citizens must be such that transparency does not become an uncritical acceptance of false facts and careless reporting. Also the bulk of information must not be such that it overwhelms and pollutes people's senses or undermines their critical capacities. Instead, citizens must be involved in critical cross-referencing and fact checking, and rewarded for such activities.

Market accountability The capacity of advertisers, politicians and specific audiences to determine the kind of content that perpetuate the existence 'deaf-mutes' and 'cyclops' must be curtailed. An awareness of the risk inherent in the 'informational architecture' created by media industries is needed. As such, training and education programs for media professionals must involve an awareness of the value-ladenness of technology and the 'framing' it entails.

Political accountability On a global scale, the relationship between the media and political realm must be such that it avoids dromocracy. This means that the capacity of one large group, whether political or corporate, to dominate news messages and information in the public realm must be resisted. The speed with which media conglomerates are appearing must therefore be considered a threat. Enhancing corporate social responsibility in the media demands careful consideration should be given regarding how 'good governance' can be implemented within complex media organizations (Van Liedekerke 2004, p. 35). This may also lead us to consider legal accountability in the media from a much broader perspective, favoring the cultural aspects of regulation (especially content rules) over ownership and competition rules (Van Liedekerke 2004). Context-specificity is more likely to take account of particular relational dynamics than a one-size-fits-all approach, and therefore more consideration should be given to industry-specific accountability challenges. In addition, Painter-Morland (2012, p. 86) urges us to challenge the assumptions that underpin our understanding of 'corporate agency.' She argues that that traditional 'agency theory' no longer offers a sensible account of how moral responsiveness should operate, and hence does not offer the same kind of control (Painter-Morland 2013, p. 4). We believe that relational accountability allows for the emergence of normative constraints that are not located in abstract principles, but in the ongoing relationships within which media professionals and the public are both embedded. The governance structures and regulative frameworks that are needed in this environment, should facilitate the sharing of information, and the public scrutiny of both political and corporate positions. Only in this way can relational accountability emerge (Table 2).

If these accountability dimensions are translated back into a definition of corporate responsibility for the media industries, it may be tentatively formulated as such: "Media companies are committed to providing the kind of information, education and example that sustains citizens' democratic engagement in creating socially, environmentally and economically flourishing societies. In order to foster relational accountability, professionals should respond to emergent norms and develop structures that facilitate good governance and transparency. In practice, this means that media professionals are relationally responsive to all societal stakeholders and as such, should design and curate informational spaces that enrich their audience's perspectives and engage them as critical participants in the search for truth(s)."

In conclusion, we consider the questions we will have to address if we want to give normative and practical content to the idea of relational accountability. 
Table 2 Accountability challenges and opportunities in the media

\begin{tabular}{|c|c|c|c|}
\hline Dimensions of media accountability & Focus group insight & $\begin{array}{l}\text { The danger from } \\
\text { Virilio's perspective }\end{array}$ & The opportunity: Relational accountability \\
\hline $\begin{array}{l}\text { Professional accountability: ethical codes } \\
\text { and performance standards }\end{array}$ & Identity crisis & 'Dromology' & Professionalism as relational responsiveness \\
\hline $\begin{array}{l}\text { Public accountability: relationship to } \\
\text { citizens }\end{array}$ & $\begin{array}{l}\text { Transparency instead } \\
\text { of objectivity }\end{array}$ & 'Dromoscopy' & $\begin{array}{l}\text { Citizen participation in fact checking and the } \\
\text { generation of multiple perspectives }\end{array}$ \\
\hline $\begin{array}{l}\text { Market accountability: system of supply } \\
\text { and demand }\end{array}$ & Monetizing speed & $\begin{array}{l}\text { 'Image-illiterates' or } \\
\text { 'deaf-mutes' }\end{array}$ & $\begin{array}{l}\text { New, creative business models which enhance } \\
\text { audience and reader participation }\end{array}$ \\
\hline Political/accountability: formal regulation & $\begin{array}{l}\text { Digital environment } \\
\text { Political interference }\end{array}$ & 'Dromocracy' & $\begin{array}{l}\text { Rethinking agency assumptions that underpin } \\
\text { governance structures. }\end{array}$ \\
\hline
\end{tabular}

\section{Conclusion: A Research Agenda Toward Relational Accountability}

Our focus group data and philosophical analysis put the current threats to the various dimensions of media accountability into sharp relief. As such, it raises certain critical questions regarding the possibility of CSR in the media industries. From a simplistic understanding of responsibility and accountability, it becomes difficult to see how CSR can be meaningfully employed. Yet, we believe that if CSR is reconceptualized in terms of relational accountability within a network of stakeholders and structures, a new understanding of the responsibilities of the media within society emerges. In many ways, responding to these threats entails walking on the tightrope of responsiveness. How can a balance be struck between responding to, but ALSO informing and negotiating public expectations? How can the public's critical scrutiny be stimulated? Though the answers to these questions are by no means clear, creating an awareness of this paradoxical charge among media professional is useful in itself. After all, nothing stimulates ethical reflection like a true moral dilemma... In this conclusion, we will not attempt to fully answer all of the emerging questions. Our aim is a more modest one, namely to highlight areas of future research into the viability of our theoretical contributions.

It is clear that in order for relational accountability to function optimally, specific actions will need to be taken. The media industries will have to steer clear of reflex democracy (dromocracy) in the technological environments that characterize contemporary media organizations. Spaces for dissent need to be utilized, precisely in and through, not despite, technological access and speed. When speed facilitates multiple feedback loops that enhance the horizon of significance of all involved, critical angles are opened. As Van Liedekerke (2004, p. 40) argues, this may require some consideration regarding how certain virtual groups may be exposed to new ideas and critical perspectives. Empirical studies exploring the accountability claims made by its participants in virtual forums, in order to reveal certain emergent values, or patterns of consensus and concern, would be important.

Media professionals have to 'curate' spaces tailored to their audience's needs, while at the same time ensuring that the public will receive the kind of information that sustains relational accountability. In terms of professional accountability, media professionals have to find ways to balance the need for immediate, consumable information with a more long-term consideration of the evolving implications of the news. This may entail offering the news in bite-sized bits, but also engaging in a consideration of broader narratives over time. It may also involve 'linking' to counter-positions and critics, and inviting audience response, rather than fostering a one-dimensional perspective on the news. As such, the value of combining of shorter news experts with longer opinion pieces and interactive discussions within news reporting, will have to be researched.

A precondition, as well as a spin-off effect of relational accountability is the willingness to engage on an ongoing basis. New technological tools within media organizations open up a variety of new possibilities in this area. Here, the speed of interactions and the open-endedness of the networks that are accessible, could be an asset in allowing diverse perspectives to be circulated. The very technology that threatens to diminish our capacity for critical reflection may ultimately enhance our deliberations if we design, and use it in the right way. This opens up many fertile areas of research, which will require the cooperation of interdisciplinary research teams. For instance, the innovations in mobile technology have rich potential for increased engagement, but the accountability implications of these engagements have not yet been researched. Engineers, philosophers, sociologists may have to consider the ethical implications of these new innovations.

If CSR is to be understood as the media's capacity to both foster and participate in various forms of relational accountability, participative checks-and-balances must be nurtured. From this perspective, professionals and their audiences are co-responsible for ongoing engagements, 
checks-and-balances, and critical questioning. This is a multilateral commitment that has to be made by media professionals, their audiences, and other institutions like governments, businesses, and NGOs. In this respect, educational institutions have an important role to play. Integrating an understanding of relational accountability into various professional curricula, as a new way of pursuing ethical constraints, could be one avenue. Studies in suitable pedagogies for shaping this new competency would be needed. An important part of this would be coming to terms with the implications of accepting a new form of agency, which does away with the autonomous transcendental subject and instead studies the structure-agency configurations that shape behavior.

Relational accountability can only function when networks and partnerships are operative, and the active protection of these networks of relationships will go a long way in fostering sustainable professions, businesses, and societal institutions. Within these complex interactions, the nurturing of professional networks is also important. Media professionals require a space for professional action, for reflection on everyday practices, and for the development of experience. This must be safeguarded despite, and maybe even by means of a fast-paced environment. Technologies have to be harnessed to build and sustain professional communities of practice. It is important that within the media profession itself, certain basic elements of professional practice have to be maintained. This is not so much about reasserting certain professional principles and duties, as it is about developing the habits of critical professional life (Stoll 2006). Professional associations have an important role to play here. In fact, they would most likely have to completely reinvent themselves. The focus will have to be less on abstract codes and rules, and more on the informing the practices of engaging with emerging technologies, studying its implications, and understanding the way in which it shapes relationships. Instead of teaching ethics as a stand-alone subject in a professional education, integration of ethical concerns across the entire university curriculum seems more appropriate.

A central part of professional life is the ability to learn through practical experience, to have the support and mentorship of experienced professionals, and to seek critical conversations with others who challenge and question your practice. Media professionals need to act in the world, both at full speed and at a slower pace, and to do this, they must contend with the ongoing process of organization that is always already going on within the media industries. To develop a meaningful account of CSR in the media industries, we have to continue to reflect both on what the media professionals and their institutions are becoming, and on the kind of relationships and responsibilities that emerge as a result. This paper is but a first step in this direction.

Acknowledgments The authors would like to thank the focus group participants in Chicago, Johannesburg, and Paris for their valuable inputs. We hope the results make them feel that their time was well spent.

Open Access This article is distributed under the terms of the Creative Commons Attribution 4.0 International License (http://crea tivecommons.org/licenses/by/4.0/), which permits unrestricted use, distribution, and reproduction in any medium, provided you give appropriate credit to the original author(s) and the source, provide a link to the Creative Commons license, and indicate if changes were made.

\section{References}

Alvesson, M., \& Skoldberg, K. (2009). Reflexive methodology. New vistas for Qualitative research. London: SAGE.

Bardoel, J., \& d'Haenens, L. (2004). Media meet the citizen: Beyond market mechanisms and government regulations. European Journal of Communication, 19, 165-194.

Barkho, L. (2010). News from the BBC, CNN and Al-Jazeera-How the broadcasters cover the Middle East. Cresskill, NJ: Hampton Press.

Berthier, N. (2006). Les techniques d'enquête en sciences sociales. Paris: Armand Colin.

Blanchet, A., \& Gotman, A. (2010). L'entretien. Paris: Armand Colin.

Bourdieu, P. (2011). On television. NY: Wiley-Blackwell.

Caroll, A. (1999). Corporate social responsibility: Evolution of a definitional construct. Academy of Management Review, 4, 268-296.

Cristian, C., \& Nordenstreng, K. (2004). Social responsibility worldwide. Journal of Mass Media Ethics, 19(1), 3-28.

Cubitt, S. (1999). Virilio and new media. Theory Culture Society, 16, 127-142.

De Singly, F. (1992). L'enquête et ses méthodes : le questionnaire. Paris: Nathan Université.

Grayston, D. (2010). Corporate responsibility and the media. Economics, Management, and Financial Markets, 5(3), 160-193.

Han, E.-K., Lee, D.-H., \& Khang, H. (2008). Influential factors of the social responsibility of newspaper corporations in South Korea. Journal of Business Ethics, 82, 667-680.

Hunter, M. and Van Wassenhove, L. (2009). Disruptive News Technologies: Stakeholder Media and the Future of Watchdog Journalism Business Models. INSEAD Working Paper Series, $1-38$.

Hydén, L., \& Bülow, P. (2003). Who's talking: drawing conclusions from focus group - some methodological considerations. Social Research Methodology, 6(4), 305-321.

Ingenhoff, D., \& Koelling, M. (2012). Media governance and corporate social responsibility of media organizations: An international comparison. Business Ethics: A European Review, 21(2), 154-167.

Kehoe, W., \& Lindgren, J. (2003). Focus groups in global marketing: Concept, methodology and implications. Marketing Management Journal, 13(2), 14-28.

Krueger, R., \& Casey, M. (2009). Focus Group: A practical guide for applied research (4th ed.). California: Sage.

McQuail, D. (1997). Accountability of media to society: principles and means. European Journal of Communication, 12(4), 511-529. 
McQuail, D. (2003). Media accountability and freedom of publication. Oxford: Oxford University Press.

McQuire, S. (1999). Blinded by the (Speed of) Light. Theory Culture Society., 16, 143-159.

Morgan, D. (1997). Focus groups as qualitative research (2nd ed.). California: Sage.

O'Carroll, A. (2008). Fuzzy holes and intangible time: Time in a knowledge industry'. Time \& Society, 17(2/3), 179-193.

Painter-Morland, M. J. (2006). Redefining accountability as relational responsiveness. Journal of Business Ethics, 66, 89-98.

Painter-Morland, M. J. (2007). Redefining accountability in a network society. Business Ethics Quarterly, 17(3), 515-534.

Painter-Morland, M. J. (2012). Rethinking responsible agency in corporations: perspectives from Deleuze \& Guattari. Journal of Business Ethics, 101(10), 83-95.

Painter-Morland, M. J. (2013). The relationship between identity crises and crises of control. Journal of Business Ethics, 114, $1-14$.

Painter-Morland, M. J., \& Deslandes, G. (2015). Rethinking authenticity and accountability: Facing up to the conflicting expectations of media leaders. Leadership. doi:10.1177/174271501 5578307.

Philipps. A., \& Witschge, T. (2012). The changing business of news: Sustainability of news journalism. In P. Lee-Wright, A. Philipps $\&$ T. Witschge (Eds.), Changing Journalism. Oxon: Routledge.

Richards, I. (2004). Stakeholders versus shareholders: Journalism, business, and ethics. Journal of Mass Media Ethics, 19(2), 119-129.

Rosa, H. (2010). Accélération, une critique sociale du temps. Paris: La Découverte.

Russell, C. (2002). Against dead time. Time \& Society, 11(2/3), 193-208.

Schiffrin, A. (2011). Bad News: How America's business press missed the story of the century. NY: The New Press.
Silverman, D. (1993). Interpreting qualitative data: Methods for analysing talk, text and interaction. London: Sage.

Steele, B. (2008). Ethical Values and Quality Control in the Digital Era. Nieman Report. Winter, 57-58.

Stoll, M. L. (2006). Infotainment and the moral obligations of the multimedia conglomerate. Journal of Business Ethics, 66 , 253-260.

Taylor, C. (1991). The ethics of authenticity. Cambridge: Harvard University Press.

Tench, R., Bowd, R., \& Jones, B. (2007). Perceptions and perspectives: corporate social responsibility and the media. Journal of Communication Management., 11(4), 348-370.

Van Liedekerke, L. (2004). Media ethics: From corporate governance to governance, to corporate social responsibility. Communications, 29(1), 27-42.

Van Puyvelde, D. (2011). Médias, responsabilité gouvernementale et secret d'état: l'Affaire Wikileaks. Le Temps des médias, 16(1), $161-172$.

Virilio, P. (2000). Information Bomb. London: Verso Books.

Virilio, P. (2005). Negative horizon: An essay in dromoscopy. London: Continuum.

Virilio, P. (2006). Speed and Politics: An Essay on Dromology. Semiotext(e), NY.

Virilio, P. (2009). Grey ecology. NY and Dresden: Atropos Press.

Virilio, P., Depardon, R., Scofino, D., Renfro, Hansen, \& El Atri, M. (2009). Native land. Actes Sud, Arles: Stop Eject.

Witschge, T., \& Gunnar, N. (2009). Journalism: A profession under pressure? Journal of Media Business Studies, 6(1), 37-59.

Young Lee, S., \& Carroll, C. (2011). The Emergence, Variation, and Evolution of Corporate Social Responsibility in the Public Sphere, 1980-2004: The Exposure of Firms to Public Debate. Journal of Business Ethics, 104, 115-131. 